\title{
Morphological, molecular characterization and taxonomic status of Triplophysa marmorata and Triplophysa kashmirensis (Cypriniformes: Nemacheilidae) from Kashmir valley, India
}

\author{
Amir Bashir ${ }^{1}$, Balwant Singh Bisht ${ }^{1}$, Javaid Iqbal Mir², Rohit Kumar ${ }^{2}$ \& \\ Rabindar Singh Patiyal ${ }^{2 *}$ \\ 1. Department of Zoology, Badshahithaul campus, HNB Garhwal University, Tehri Garhwal-249199; \\ amirbashir207@gmail.com, bsbisht.1256@gmail.com \\ 2. Directorate of Coldwater Fisheries Research, Anusandhan Bhawan, Bhimtal, Uttarakhand, India-263136; \\ kr_3487@yahoo.in, r.javaid@rediffmail.com,rspatiyal01@rediffmail.com \\ * Correspondence
}

Received 11-VI-2015. Corrected 30-X-2015. Accepted 20-XI-2015.

\begin{abstract}
In India the distribution of genus Triplophysa has been reported only in the upper drainage of the Indus River in Jammu and Kashmir and Lahul and Spiti area of Himachal Pradesh. There is no study on the taxonomic characterization of this genus from Kashmir Himalaya. Therefore the present study was aimed to characterize two important fish species Triplophysa marmorata and T. kashmirensis from Kashmir valley, by using morphometric and molecular tools. It is difficult to discriminate these two species due to the poor quality of original descriptions, and the lack of good reviews. Keeping this in view, a morphometric and molecular study was conducted. Morphometric data were analyzed by using univariate analysis of variance (ANOVA) and multivariate analyses (Principal component analysis) and mtDNA marker Cytochrome oxidase 1 was used for molecular support. Altogether, 22 morphometric characters were used and 15 characters were found significantly variable $(\mathrm{P}<0.05)$. First two components of principal component analysis (PCA) i.e. PC1 and PC2 grouped these two species into separate clusters. The Cytochrome oxidase 1 analysis showed that the mean intraspecific nucleotide divergence (K2P) was 0.001 and interspecific nucleotide divergence was 0.007 . Despite having low K2P divergence, these two species got separated into two distinct clades in both Neighbour joining (NJ) and Unweighted Pair Group Method with Arithmetic Mean (UPGMA) tree building methods. But the pattern of clade formation showed that these species were recently radiated from each other and may have the same ancestor. Furthermore, these two species were found closer to Nemacheilidae than to Balitoridae family in the phylogenetic analysis. The molecular divergence between these species was also supported by variance in morphometric data. This work may build the base for the revision of taxonomic identity of these two important fishes of genus Triplophysa. The present investigation formulated that, based on morphological and mtDNA COI sequences analysis, these two taxonomic Triplophysa species should be considered as valid. The results may further assist to enhance the knowledge of the ichthyologists in understanding the ichthyofauna of Kashmir Valley and will help them in planning strategies for conservation and management of these less studied small indigenous species along their natural range of distribution. Rev. Biol. Trop. 64 (2): 473-482. Epub 2016 June 01.
\end{abstract}

Key words: Triplophysa, principal component analysis, molecular characterization, cytochrome oxidase 1, Kashmir valley.

Genus Triplophysa (Rendahl, 1933) belongs to the family Balitoridea, subfamily Nemacheilinae having 124 nominal species in this genus all over the world ( $\mathrm{Li}, \mathrm{Chen}, \& \mathrm{Hu}$, 2015). The distribution of this genus ranges from drainages of China and upper Indus to
Tigris River basin of West Asia, and in different river drainages of Central Asia (Zhou \& Cui, 1997). In India the distribution of this genus has been reported only in the upper drainage of the Indus River in Jammu and Kashmir, and Lahul and Spiti area of Himachal Pradesh (Kullander, 
Fang, Delling, \& Ahlander, 1999). Triplophysa is a species-rich genus currently having about, 116 recognized species, 99 of which have so far been documented from China (Li, et al., 2008). In Indian 10 Triplophysa has been reported by Menon (1987). The species of Triplophysa have a distinct sexual dimorphism: male on both sides of the head posses tubercle-bearing elevated skin, and a thick tuberculate pad on the dorsal surfaces of the broadened and widened pectoral-fin rays (Zhu, 1989).

In Kashmir Valley, Heckel (1838) described two scaleless fish species which he called Cobitis marmorata and C. vittata, but Kullander et al. (1999) referred them as $T$. marmorata and T. kashmirensis respectively and placed them in family Balitoridae. They have a relatively slender caudal peduncle that is sometimes described as 'whiplike' in some species. Triplophysa, species range mostly between about 60 to $190 \mathrm{~mm}$ SL in length. Nevertheless, the taxonomic status of various Triplophysa species described from the upper Indus drainage, especially those recorded from the Kashmir Valley and Ladakh is not well understood (Kullander et al., 1999). Triplophysa marmorata specimens are identified by having shorter lateral line length and shorter caudal peduncle than T. kashmirensis, but in other morphometric characters, Triplophysa marmorata is similar to T. kashmirensis and are identified as such. However, Kullander et al. (1999) suggested that the morphometry variation may be influenced by habitat and suggested further study to clear the taxonomic status of these two species. Moreover due to various anthropogenic activities, such as overfishing, water contamination, dam construction, and habitat alteration, wild fisheries of these species have declined its population dramatically, and the distribution range has been shrinking rapidly from the last decades (Gao, Tang, Qiao, Yang, \& Chen, 2011). For monitoring speciesspecific conservation program, proper identification of the taxonomic unit to be conserved is fundamental. Inaccurate taxonomy leads to the lack of identification and threats to the survival of important components of biodiversity. On the other hand, conservation resources can be a waste by focusing on supposedly rare species that are merely nongenetic phenotypic variants of a common species (Avise, 1994).

Molecular characterization is an initiative for taxon recognition, molecular signature and classification of animals based on DNA sequences. Molecular markers are powerful tools for solving questions concerning ecology, evolution, and conservation of several fish taxa (Wilson, Woods, Maina, \& White, 2000; Thangaraj \& Lipton, 2010). Presently, the mitochondrial markers are popular DNA markers used for species discrimination (Teletchea, 2009). These markers have been already proven as an important tool to address the molecular systematics status of various species (Lara et al., 2010). The idea of using the standardized cytochrome c oxidase subunit I gene (COI) as a method to identify species was proposed by Hebert, Cywinska, Ball and deWaard (2003) and from that time, over 1.9 million specimens, approximately belonging to 172000 species, including 9502 fishes has been characterized (Ratnasingham \& Hebert, 2007). The methodology to identify species is based on differences in the sequences of a short standardized DNA fragment from the mitochondrial COI gene ( $\sim 650 \mathrm{bp})$ (Hebert et al., 2003).

The present investigation aimed to study the taxonomical and molecular characterization of two Triplophysa species from the Western Himalayan region of India, based on the results of morphology and mitochondrial gene, cytochrome oxidase 1 (CO 1) sequence analysis. The study also attempted to clarify the systematic status of these species using the corresponding CO 1 sequences of some other fish species of family Balitoridae and Nemacheilidae retrieved from GenBank. The results of this study could form taxonomic base for the revision of identity for these species in India subcontinent. The baseline data generated in this investigation will be useful to fisheries managers to make efforts for the conservation of this species group. 


\section{MATERIAL AND METHODS}

Sample collection: A total of nine specimens for molecular analysis per species and a total 92 specimens (46 samples per species) for morphometric analysis were collected from river Jhelum at Brazloo Kulgam $\left(75^{\circ} 2^{\prime} 41.79^{\prime \prime} \mathrm{E}-33^{\circ} 38^{\prime} 42.588^{\prime \prime} \mathrm{N}\right)$ and Dal Lake (7451'24.118" E - 34 ${ }^{\circ} 5^{\prime} 19.722^{\prime \prime}$ N) in Kashmir, India (Table 1). The fish samples were collected seasonally during winter (DecemberMarch), pre-monsoon or summer (April-June), monsoon or rainy (July-September) and postmonsoon or autumn (October-November) from March 2014 to April 2015 by using cast nets with the help of local fishermen. Identification of fishes was done following the taxonomic keys of Talwar and Jhingran (1999) and Kullander et al. (1999). Fin tissue samples were collected from the caudal fin and preserved in $95 \%$ ethanol. Voucher specimens were preserved in $10 \%$ formaldehyde solution and were deposited in museum of Directorate of Coldwater Fisheries Research, Uttarakhand, India.

Morphometric analysis: The following morphometric characters were analyzed for both fish species: Standard Length: SL, Body Depth/Maximum Body Depth: MBD, Snout Length: SnL, Head length: HL, Depth Dorsal/Dorsal fin height: DFH, Base dorsal/dorsal fin Length: DFL, Base Anal Length/Anal fin length: AFL, Length Pectoral/pectoral fin height: PFH, Length Pelvic/Ventral fin height:
VFH, Straight Lateral line Length: SLLL, Snout to dorsal length/Pre dorsal Length: PrDFL, Snout to pelvic length/pre Ventral Length: PrVFL, Snout to pectoral length/Pre Pectoral Length: PrPFL, Snout to Anal length/Pre Anal Fin length: PrAFL, Depth Caudal/Minimum Body Depth: MinBD, Length Caudal/Caudal Fin Length: CFL, Upper Jaw Length: UJL, Sub-Orbital Width: SoW, Eye Diameter: ED, distance from anal fin to caudal fin base: $\mathrm{DACB}$, Distance $\mathrm{b} / \mathrm{w}$ pectoral and anal fin: DPA, and Distance $b / w$ ventral and Pectoral: DVP. All the measurements were taken using electronic digital calipers (Mitiyo make) to the nearest $0.01 \mathrm{~mm}$ (Mir, Patiyal, \& Sahoo, 2015).

All the morphometric characteristics were log-transformed and standardized for numerical analysis. The raw morphometric data were firstly transformed to common logarithms in order to increase linearity and multivariate normality and then size-dependent variation was removed using an allometric approach (Elliott, Haskard, \& Koslow, 1995).

$$
\text { Mtrans }=M(\text { Ls / Lo }) b
$$

Whereas Mtrans is the transformed measurement, $\mathrm{M}$ is the original measurement, $\mathrm{b}$ is the within group slope regression of the $\mathrm{M}$ versus $\mathrm{SL}$, Ls is the standard length of the fish, and Lo mean the overall mean of the standard length.

The descriptive statistics for each morphometric characters were obtained. A one-way

TABLE 1

Species information, Voucher ID, NCBI GenBank accession number and collection sites of species studied from the Kashmir valley

\begin{tabular}{|c|c|c|c|c|c|}
\hline Species & Specimen ID & Voucher ID & $\begin{array}{l}\text { Date of } \\
\text { Collection }\end{array}$ & $\begin{array}{c}\text { GenBank } \\
\text { accession number }\end{array}$ & Collection locality \\
\hline T. marmorata & $\begin{array}{l}\text { TMAK_01 } \\
\text { TMAK_02 } \\
\text { TMAK_03 } \\
\text { TMAK_05 }\end{array}$ & $\begin{array}{l}\text { DCFR_MG_CCAK01 } \\
\text { DCFR_MG_CCAK02 } \\
\text { DCFR_MG_CCAK03 } \\
\text { DCFR_MG_CCAK05 }\end{array}$ & $\begin{array}{l}\text { June } \\
2014\end{array}$ & $\begin{array}{l}\text { KP795440 } \\
\text { KP795441 } \\
\text { KP795442 } \\
\text { KP795443 }\end{array}$ & $\begin{array}{l}\text { Srinagar } \\
\text { (Hazratbal) } \\
\text { Dal Lake }\end{array}$ \\
\hline T. kashmirensis & $\begin{array}{l}\text { TKAK_01 } \\
\text { TKAK_03 } \\
\text { TKAK_04 } \\
\text { TKAK_05 } \\
\text { TKAK_m/k4 }\end{array}$ & $\begin{array}{l}\text { DCFR_MG_TKAK } 01 \\
\text { DCFR_MG_TKAK } 03 \\
\text { DCFR_MG_TKAK } 04 \\
\text { DCFR_MG_TKAK 05 } \\
\text { DCFR_MG_TKAK_m/k4 }\end{array}$ & $\begin{array}{c}\text { July } \\
2014\end{array}$ & $\begin{array}{l}\text { KP795435 } \\
\text { KP795436 } \\
\text { KP795437 } \\
\text { KP795438 } \\
\text { KP795439 }\end{array}$ & Brazloo Kulgam \\
\hline
\end{tabular}


analysis of variance (ANOVA) was carried out on each transformed morphometric variable. Significant variables were retained and then subjected to Principal component analysis (PCA). All statistical analyses were done using the statistical analysis system (SPSS.20ver.).

Isolation of Genomic DNA, PCR Amplification and Sequencing: A total of nine specimens of both the species were collected from river Jhelum and Dal Lake in Kashmir, India. Total genomic DNA was isolated from the fin tissue following Phenol: Chloroform: Isoamyl alcohol method of Sambrook, Fritsch and Maniatis (2001). Both quality and quantity of the genomic DNA was assessed using 0.8 $\%$ agarose gel electrophoresis (Takara Bio, Japan) and Nanodrop (Thermo Fisher, USA), respectively. The genomic DNA was stored at $-20{ }^{\circ} \mathrm{C}$ for future use. The cytochrome $\mathrm{c}$ oxidase subunit I (COI) gene was amplified with primers FishF1-5'-TCAACCAACCACAAAGACATTGGCAC-3' and FishR-1 5'-TAGACTTCTGGG TGGCCAAAGAATCA-3' (Ward, Zemlak, Innes, Last, \& Hebert, 2005 ) in a $50-\mu \mathrm{L}$ volume with $100 \mathrm{ng}$ template DNA, 10 pmole of each specific primer, $250 \mu \mathrm{M}$ of each dNTPs, $1.0 \mathrm{U}$ of Taq DNA polymerase and $1 \mathrm{x}$ Taq buffer containing 1.5 $\mathrm{mM} \mathrm{MgCl2}$. The PCR conditions consisted of initial denaturation at $94{ }^{\circ} \mathrm{C}$ for $3 \mathrm{~min}, 35$ cycles of denaturation at $94{ }^{\circ} \mathrm{C}(40 \mathrm{~s})$, annealing at $58^{\circ} \mathrm{C}(40 \mathrm{~s})$, extension $72{ }^{\circ} \mathrm{C}(60 \mathrm{~s})$ and a single final extension at $72{ }^{\circ} \mathrm{C}$ for $10 \mathrm{~min}$ and product storage at $4{ }^{\circ} \mathrm{C}$. The PCR products were visualized on $1.2 \%$ agarose gel and the amplicons were purified and sequenced in both directions in automated genetic analyzer (ABI 3730, Applied Biosystem, USA) following Bigdye ${ }^{\circledR}$ terminator v.1.1 Cycle Sequencing Kit (Applied Biosystem, USA).

Sequence analysis: The raw sequences were initially trimmed to remove low quality region or primer sequences, forward and reverse sequences were aligned using the CLC Genomic Workbench v.7.5.1 (Quaigen, Germany). Finally, 681bp nucleotide alignment was obtained and used for further studies. The $681 \mathrm{bp}$ assembled sequences were Blast searched (NCBI database) using BLASTN toolkit for confirmation. Kimura two-parameter (K2P) distance model (Kimura, 1980) was used to calculate nucleotide divergences. The mean, minimum and the maximum nucleotide divergence within and between species were computed. The Sequences divergence was estimated by using MEGA6 (Tamura, Stecher, Peterson, Filipski, \& Kumar, 2013). To conduct the phylogenetic analysis, we downloaded COI sequences of 23 species (genera: Schistura, Nemacheilus, Paracobitis, Lepturichthys, Lefua, and Triplophysa) from GenBank database. As outgroups, from NCBI database, also we downloaded sequences of Homatula and Barbatula for family-level comparative study and Acanthocobitis and Leptobotia for subfamily-level comparative study (Table 1). The Model test v3.6 program (Posada \& Crandall, 1998) was run in order to calculate the best substitution model for analysis. The model with the highest Akaike information criterion value, i.e. K2p model, was selected for further analysis using the nearest neighbor interchange algorithm. Graphical representation of the divergence pattern between the two species was created by using Neighbour-joining (NJ) and Unweighted Pair Group Method with Arithmetic Mean (UPGMA) tree methods of K2P distances (Saitou \& Nei, 1987). In the two chosen subgroups of fish, for both graphical representations bootstrapping was performed in MEGA6 (Tamura et al., 2013) with 1000 replications.

\section{RESULTS}

Morphometric analysis: By applying ANOVA on 22 morphometric characters only 15 showed significant difference in their mean values $(\mathrm{P}<0.05)$. The significant variables included BD, HL, DFH, DFL, PFH, SLL, PrDFL, PrVFL, PrAFL, MinBD, CFL, SoW, DACB, DPA and DVP. Principal component analysis of the 15 significant variables produced five principal components (PCs). The 
first and second PC contributed $93.341 \%$ and $1.7136 \%$ respectively, while the third PC contributed $1.1424 \%$ to the total variance. A PCA plot of PC1 vs. PC2 was generated which grouped the species into two separate clusters (Fig. 1).

Molecular analysis: A total of nine COI sequences were sequenced from both fish species. After exclusion of the primer sequence and low-quality base trimming, sequence alignment yielded $681 \mathrm{bp}$ per taxon. The NCBI BLASTx of $681 \mathrm{bp}$ COI of both species in the present study revealed that no sequences of the species were present but showed similarity match with Triplophysa stoliczkae. Both T. marmorata and T. kashmirensis showed 92 $\%$ similarity (E value 0.0) with Triplophysa stoliczkae. Well defined peaks indicated that no co-amplification of nuclear pseudogenes has occurred. In T. marmorata the COI sequence analysis across species revealed average nucleotide frequencies as $24.6 \%$ (A), $30.1 \%(\mathrm{~T})$, $26.9 \%(\mathrm{C})$ and $18.4 \%(\mathrm{G})$ whereas, in $T$. kashmirensis the average nucleotide frequencies was $24.1 \%$ (A), $30.4 \%$ (T), 26.9\% (C) and $18.5 \%(\mathrm{G})$. All the sequences have been deposited in GenBank (Accession numbers: Table 1). The interspecific sequence divergence between the two species was high as compared to intraspecific sequence divergence. There was no nucleotide divergence (K2P) between individual species of $T$. marmorata, whereas, in T. kashmirensis it was 0.001. Furthermore, the mean nucleotide divergence between these two species was 0.007 (Table 2). Out of $681 \mathrm{bp}, 676$ were constant sites, whereas, five sites were variable/singleton between the two species. The variable sites were at nucleotide position number 127, 166, 444, 486 and 639.

In this study, the overall estimated Transition/Transversion bias (R) was 0.67 . It indicated

TABLE 2

Estimates of average evolutionary divergence over sequence pairs within and between species

\begin{tabular}{lcccc}
\multicolumn{1}{c}{ Species } & Minimum & Maximum & mean & Standard Error \\
T. marmorata & 0.00 & 0.000 & 0.000 & 0.00 \\
T. kashmirensis & 0.00 & 0.001 & 0.001 & 0.001 \\
Between Species & 0.006 & 0.007 & 0.007 & 0.003 \\
\hline
\end{tabular}

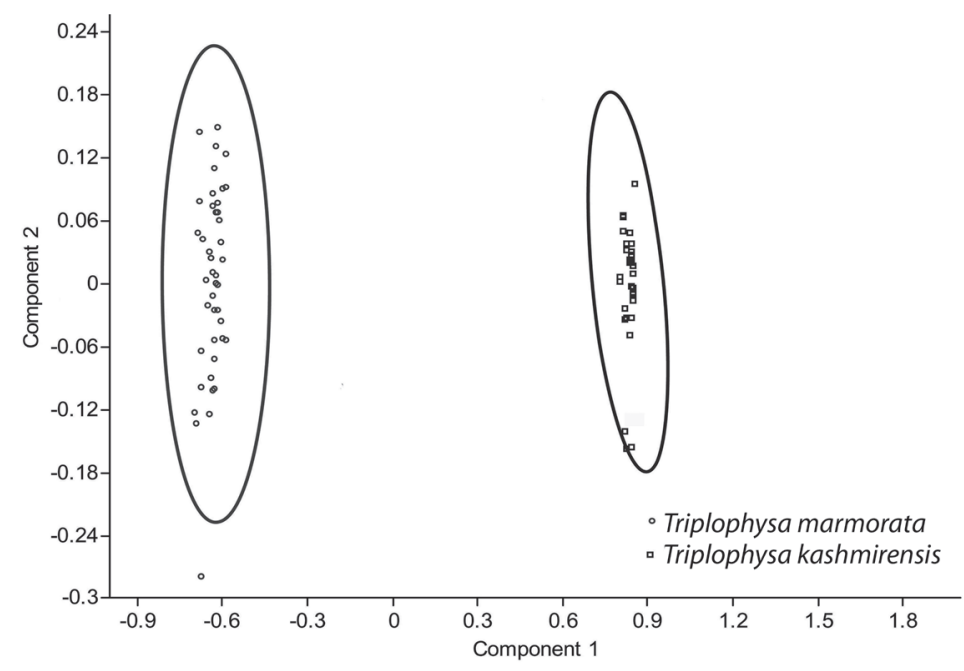

Fig. 1. Principal component plot showing separate cluster of two Triplophysa species. 
that the COI sequences are not saturated and can discriminate species. The maximum log likelihood for this study was -981.57 . The NJ and UPGMA using K2P genetic divergence were created to provide a graphic representation of the patterns of divergences (Fig. 2 and Fig. 3). Despite having low nucleotide divergences (COI) between the species, both the species were separately resolved as monophyletic groups in both tree-building methods (NJ and UPGMA).

\section{DISCUSSION}

In the present study, the numbers of morphometric measurements used are considered to be of adequate number for identification and differentiation of these two fish species. Compared with the earlier reports of Kullander et al. (1999) and Talwar and Jhingran (1991) who reported only significant variation in MBD, SLL and MinBD between the species, this study reported significant variation in

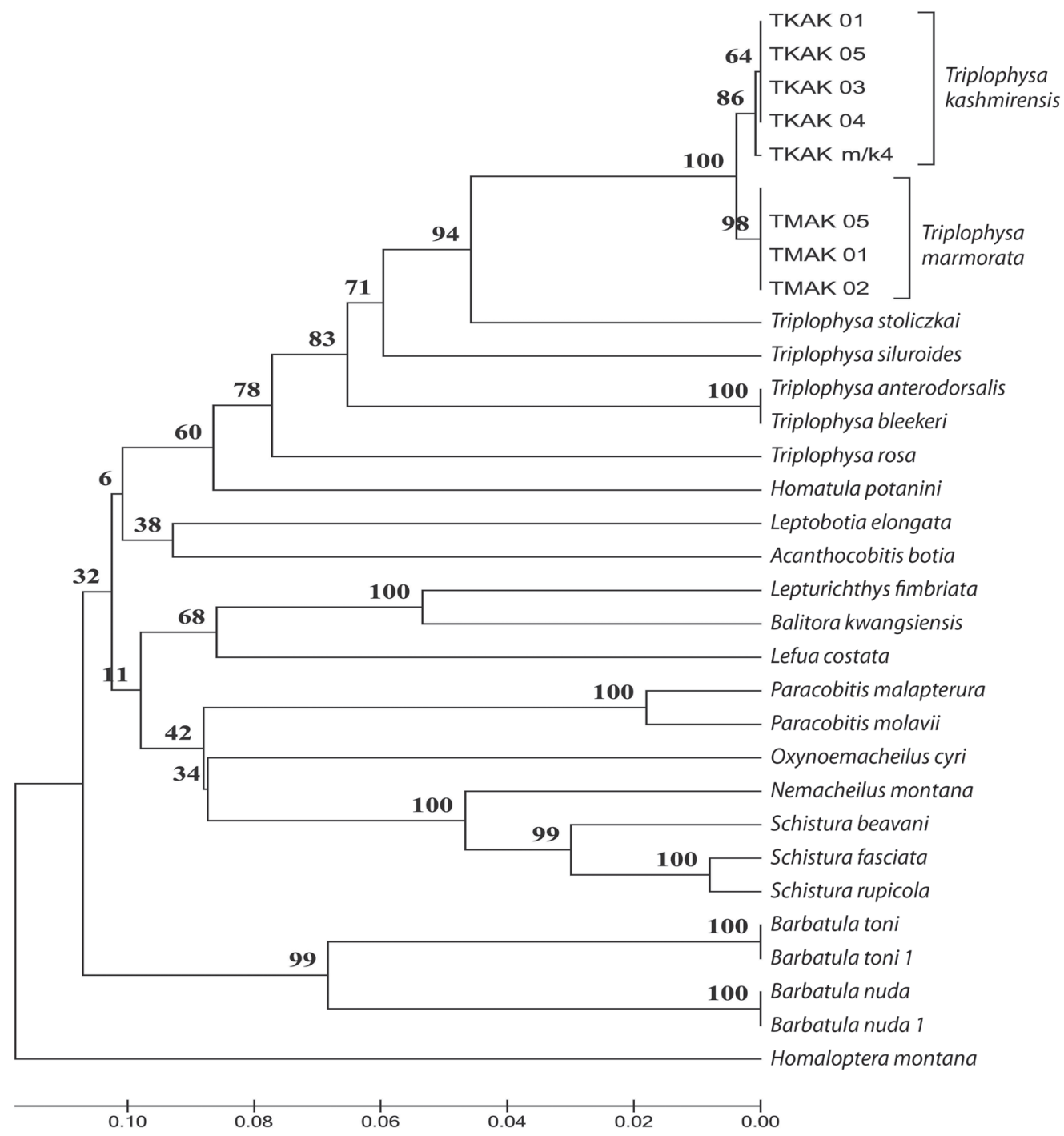

Fig. 2. UPGMA tree of Kimura two-parameter (K2P) distances.

Numbers above branches refer to bootstrap proportions among 1000 bootstrap replicates. 


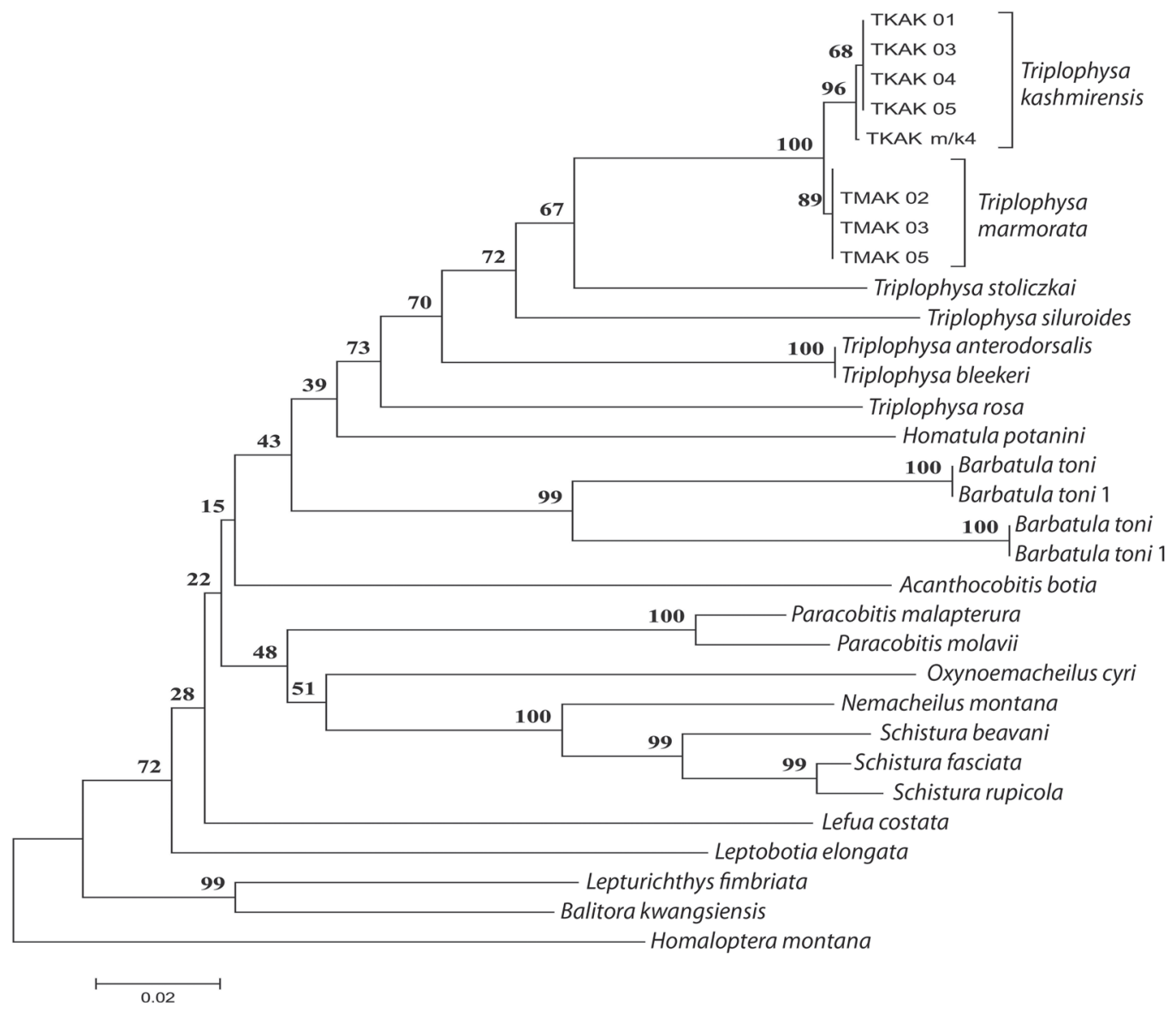

Fig. 3. Neighbour-joining tree of Kimura two-parameter (K2P) distances. Numbers above branches refer to bootstrap proportions among 1000 bootstrap replicates.

15 morphometric characters that can be used in their identification and differentiation. For most of the morphometric characters the variation within species was less evident, and this suggests that each species consists of a phenotypically and genetically homogeneous group.

Our study provides the first molecular characterization of these species from Kashmir valley. The overall base composition of both T. marmorata and T. kashmirensis was in accordance with the study of the complete $\mathrm{mt}$ genome of $T$. bleekeri by Jiuxuan, Kun, Shengjuan, Xiuyue, \& Zhaobin (2015) having high $\mathrm{A}+\mathrm{T}$ bases. The average $\mathrm{K} 2 \mathrm{P}$ divergence within conspecific specimens was found only
0.001 and among congeneric species 0.007. The result of our study was in contrast with the results of previous studies. Hubert et al. (2008) found average K2P values of $0.27 \%$ (conspecific) and $8.37 \%$ (congeneric), discriminating $93 \%$ of the species while studying freshwater fishes from Canada. In another study, $93 \%$ of freshwater fishes were discriminated from Mexico and Guatemala showing average K2P values of $0.45 \%$ in conspecific and $5.1 \%$ in congeneric (Valdez-Moreno, Ivanova, ElíasGuitiérrez, Contreras-Balderas, \& Hebert, 2009). Ward, Hanner and Hebert (2009) tried to analyze the values of $\mathrm{K} 2 \mathrm{P}$ genetic divergence among 1088 fish species and found average 
K2P values of $0.3 \%$ in conspecific and 8.4 $\%$ in congeneric, discriminating about 97.5 $\%$ of the species. Recently, Lara et al. (2010) discriminated $96 \%$ of the freshwater fish species from Cuba and found average K2P values of $0.6 \%$ in conspecific and $9.1 \%$ in congeneric, discriminating $96 \%$ of the species. The relatively low value in this study may be due to limited sampling, though we have taken more than one specimen of each species and had tried to sample the maximum variation within both species.

Moreover, the sequence divergence between the two species is very low that it does not follow the $>2 \%$ approach (Ward et al., 2009). As low K2P divergences were reflected between the two species, these low values may be an indication of recent radiation of these species. Perdices, Doadrio and Bermingham (2005) and Ornelas-Garcia, Dominguez-Dominguez and Doadrio (2008) proposed recent radiation for Mesoamerica fish species. Similarly Hubert et al. (2007) pointed to a recent radiation of some groups of freshwater fishes from South America and suggested that these patterns could be found for most Neotropical freshwater fishes. The phlyogenetic analysis showed that both species T. marmorata and T. kashmirensis form separate clades, though it becomes evident that these are too close to each other. Furthermore, both phlyogenetic tree shows that they are more close to Triplophysa stoliczkae thus representing true species of Triplophysa genus. Kullander et al. (1999) places these species into Balitoridae family, but the phlyogenetic relationship showed that these two species were more close to Nemacheilidae family than to Balitoridae.

This study has validated the fact that these are two different species radiated recently from each other. Based on our observation, the inferred phylogenetic closeness indicates that the assignment of these species among the family Balitoridae is improper, and they are closer to family Nemacheilidae. The identification keys developed in the present investigation will be useful in better management and conservation of these species across their natural range of distribution.

\section{ACKNOWLEDGMENT}

We would like to acknowledge director Directorate of Coldwater Fisheries Research for providing necessary facilities for carrying out this study. The financial support provided by Hemwati Nandan Bahuguna Garhwal University, Srinagar, as student fellowship to first author is duly acknowledged. We are also indebted to A. Barat, P. K. Sahoo, Principal Scientist, and S. Ali, Scientist of molecular genetics laboratory of Directorate of Coldwater Fisheries Research for providing valuable guidance and input during this study.

\section{RESUMEN}

En la India, la distribución del género Triplophysa se ha reportado solo en la parte superior del río Indus en Jammu, Kashmir, Lahul y Spiti en el área de Himachal Pradesh. No existen publicaciones acerca de la caracterización taxonómica de este género en Kashmir Himalaya. Por lo tanto, en este estudio se caracterizaron dos especies del valle de Kashmir: Triplophysa marmorata y T. kashmirensi, mediante el uso de herramientas morfométricas y moleculares. Es difícil diferenciar entre estas dos species debido a las vagas descripciones originales y a la falta de buenas revisiones. Debido a esto se realizó un estudio morfométrico y molecular. Los datos morfométricos se analizaron mediante un ANOVA y un análisis de componentes principales y el marcador del gen de la citocromo oxidasa 1 se usó para apoyo molecular. En general, se usaron 22 caracteres morfométricos y 15 fueron significativos $(\mathrm{P}<$ 0.05). Los dos primeros componentes del análisis de components principales (PCA), PC1 y PC2, agruparon estas dos especies en clusters separados. El análisis con citocromo oxidasa 1 mostró que el promedio de divergencia del nucleótido intraespecífico (K2P) fue de 0.001 y la divergencia del nucleótido intraespecífico fue de 0.007. A pesar de la baja divergencia de K2P, estas dos species se separan en dos clados diferentes tanto por el método NJ como por el método UPGMA. Sin embargo, el patrón de formación del clado mostró que estas species radiaron recientemente una de la otra y que podrían tener un ancestro en común. Además, en el análisis filogenético estas dos especies se encontraron más cerca de la familia Nemacheilidae que de Balitoridae. La divergencia molecular entre estas dos especies también fue respaldada por la varianza en los datos morfométricos. Este estudio puede establecer la base para una revisión taxonómica de estos dos importantes peces 
del género Triplophysa. Esta investigación postuló que, basada en análisis morfológicos y de secuencia de ADNm COI, estas dos especies taxonómicas de Triplophysa deben considerarse válidas. Los resultados pueden contribuir a mejorar el conocimiento de los ictiólogos en la comprensión de la ictiofauna del valle de Kashmir y les ayudará a planear estrategias de conservación y manejo de estas dos pequeñas especies indígenas y poco estudiadas en su rango de distribución natural.

Palabras clave: Triplophysa, análisis de componentes principales, caracterización molecular, citocromo-oxidasa 1 , valle de Kashmir.

\section{REFERENCES}

Avise, J. C. (1994). Molecular markers, natural history and evolution. New York: Chapman and Hall, Inc.

Elliott, N. G., Haskard, K., \& Koslow, J. A. (1995). Morphometric analysis of orange roughy (Hoplostethus atlanticus) off the continental slope of southern. Australian Journal of Fish Biology, 46, 202-220.

Gao, S. B., Tang, H. Y., Qiao, Y., Yang, Z., \& Chen, J. S. (2011). Status of fishery resources in the main stream of the lower reaches of Jinsha River. Journal of Hydroecology, 34, 44-49 (in Chinese).

Hebert, P. D. N., Cywinska, A., Ball, S. L., \& deWaard, J. R. (2003). Biological identifications through DNA barcodes. Proceedings of Royal Society of London B Biological Sciences, 270, 313-321.

Heckel, J. J. (1838). Fische aus Cashmir gesammelt und herausgegeben von Carl Freiherrn v. Hügel. Mechitaristen, Wien, 110 pp, 13 pls.

Hubert, N., Duponchelle, F., Nunez, J., Garcia-Davila, C., Paugy, D., \& Renno, J. F. (2007). Phylogeography of the piranha genera Serrasalmus and Pygocentrus: Implications for the diversification of the Neotropical ichthyofauna. Molecular Ecology, 16, 2115-2136.

Hubert, N., Hanner, R., Holm, E., Mandrak, N. E., Taylor, E., Burridge, M., Watkinson, D., Dumont, P., Curry, A., Bentzen, P., Zhang, J., April, J., \& Bernatchez, L. (2008). Identifying Canadian freshwater fishes through DNA barcodes. PLosONE, DOI, 10.1371/ journal.pone.0002490.

Jiuxuan, Li., Kun, Y., Shengjuan, S., Xiuyue, Z., \& Zhaobin, S. (2015). Complete mitochondrial genome of Triplophysa bleekeri (Cypriniformes: Balitoridae: Nemacheilinae), and analysis of mitochondrial genetic variability among Triplophysa species. Mitochondrial DNA, DOI, 10.3109/19401736.2014.1003878.

Kimura, M. (1980). A simple method of estimating evolutionary rate of base substitutions through comparative studies of nucleotide sequences. Journal of Molecular Evolution, 16, 111-120.

Kullander, S. O., Fang, F., Delling, B., \& Ahlander, E. (1999). The fishes of the Kashmir Valley. In L. Nyman (Ed.), River Jhelum, Kashmir Valley: Impact on the Aquatic Environment (pp. 100-167). Goteberg, Sewden: Swedmar.

Lara, A., Ponce de Leon, J. L., Rodriguez, R., Casane, D., Cote, G., Bernatchez, L., \& Garcia-Machado, E. (2010). DNA barcoding of Cuban freshwater fishes: Evidence for cryptic species and taxonomic conflicts. Molecular Ecology Resources, 10, 421-430.

Li, W. J., Chen, X. C., \& Hu, Y. P. (2015): A new species of the genus Triplophysa (Nemacheilinae), Triplophysa qilianensis sp. nov, from Qinghai, China. Zootaxa, 3905, 418-424.

Li, W. X., Yang, H. F., Chen, H., Tao, C. P., Qi, S. Q., \& Han, F. (2008) A new blind underground species of the genus Triplophysa (Balitoridae) from Yunnan, China. Zoological Research, 29, 674-678.

Menon, A. G. K. (1987). The fauna of India and the adjacent countries. Pisces Vol. IV Teleostei Cobitoidea Part I Homalopteridae. Director, Zoological Survey of India, Calcutta.

Mir, J. I., Patiyal, R. S., \& Sahoo, P. K. (2015). Lengthweight relationships of 10 fish species from a Ganga River Basin tributary, Uttarakhand, India. Journal of Applied Ichthyology, 31, 431-432.

Ornelas-Garcia, C. P., Dominguez-Dominguez, O., \& Doadrio, I. (2008). Evolutionary history of the fish genus Astyanax Baird \& Girard (1854) (Actynopterigii, Characidae) in Mesoamerica reveals multiple morphological homoplasies. BMC Evolutionary Biology, 8,340 .

Perdices, A., Doadrio, I., \& Bermingham, E. (2005). Evolutionary history of the synbranchid eels (Teleostei: Synbranchidae) in Central America and the Caribbean islands inferred from their molecular phylogeny. Molecular Phylogenetic Evolution, 37, 460-473.

Posada, D., \& Crandall, K. A. (1998). MODELTEST: Testing the model of DNA substitution. Bioinformatics, $14,817-818$.

Ratnasingham, S., \& Hebert, P. D. N. (2007). BOLD: The Barcode of Life Data System (www.barcodinglife. org). Molecular Ecology Notes, 7, 355-364.

Rendahl, E. (1933). Weitere Untersuchungen iiber den Schultergiirtel und die Brustflossenmuskulatur der Cobitiden. Arkiv för Zoologi, 25, 1-37.

Saitou, N., \& Nei, M. (1987). The neighbour-joining method: a new method for reconstructing evolutionary trees. Molecular Biology Evolution, 4, 406-425. 
Sambrook, J., Fritsch, E. F., \& Maniatis, T. (2001). Molecular Cloning, A Laboratory Manual, 2nd Ed. New York: Cold Spring Harbor Laboratory Press.

Talwar, P. K., \& Jhingran, A. G. (1991). Inland Fishes of India and Adjacent Countries. N. Delhi: Oxford and IBH publishing Co.

Tamura, K., Stecher, G., Peterson, D., Filipski, A., \& Kumar, S. (2013). MEGA6: Molecular Evolutionary Genetics Analysis version 6.0. Molecular Biology Evolution, 30, 2725-2729.

Teletchea, F. (2009). Molecular identification methods of fish species: Reassessment and possible applications. Reviews in Fish Biology and Fisheries, 19, 55-85.

Thangaraj, M., \& Lipton, A. P. (2010). Genetic identity of three Indian populations of three spotted seahorse, Hippocampus trimaculatus. Advanced Biological Resources, 4, 37-41.

Valdez-Moreno, M., Ivanova, N. V., Elías-Guitiérrez, M., Contreras-Balderas, S., \& Hebert, P. D. N. (2009). Probing diversity in freshwater fishes from Mexico and Guatemala with DNA barcodes. Journal of Fish Biology, 74, 377-402.

Ward, R. D., Hanner, R., \& Hebert, P. D. N. (2009). The campaign to DNA barcode all fishes. Journal of Fish Biology, 74, 329-356.

Ward, R. D., Zemlak, T. S., Innes, B. H., Last, P. R., \& Hebert, P. D. N. (2005). DNA barcoding Australia's fish species. Philosophical Transactions Royal Society of Biological Sciences, 360, 1847-1857.

Wilson, P. J., Woods, C. M., Maina, J. N., \& White, B. N. (2000). Genetic structure of Lake Magadi tilapia populations. Journal of Fish Biology, 56, 590-603.

Zhou, W., \& Cui, G. H. (1997). Fishes of the genus Triplophysa in the Yuanjiang River (upper Red River) basin of Yunnan, China, with description of a new species. Ichthyological Exploration of Freshwaters, 8, 177-183.

Zhu, S. Q. (1989). The Loaches of the Subfamily Nemacheilinae in China (Cypriniformes: Cobitidae). Nanjing: Jiangsu Science and Technology Publishing House. 